Discourse and Communication for Sustainable Education, vol. 7, no. 1, pp. 82-99, 2016

\title{
Primary Science Teaching - Is it Integral and Deep Experience For Students?
}

\author{
Inge Timoštšuk \\ Tallinn University, Estonia
}

\begin{abstract}
Integral and deep pedagogical content knowledge can support future primary teachers' ability to follow ideas of education for sustainability in science class. Initial teacher education provides opportunity to learn what and how to teach but still the practical experiences of teaching can reveal uneven development of student teachers' professionality. The aim of the study is to describe how future primary teachers reflect on their experiences about science teaching and what components of science pedagogical content knowledge they see as meaningful. A questionnaire and interviews were used. The results reveal the deep impact of teaching practice on students' understanding of the role of a teacher in supporting pupils' acquisition of scientific skills. The experiences described are related more to teaching and learning in general and less with science-specific factors. Nevertheless, students described changes in mission e.g. how they learned about their role through pupils' achievements and thinking about science. Changes in professional identity were mentioned rarely but this could point to an underestimated resource issue for teacher education. Positive changes in professional identity may help students to decide to choose more integral strategies in science teaching and thus promote more sustainability oriented teaching.
\end{abstract}

Keywords: education for sustainable development, pedagogical content knowledge, primary science, student teachers, teachers' learning experiences

\section{Introduction}

The experiences student teachers have in initial teacher education influence both their career choice (Cochran-Smith et al, 2012; Timoštšuk \& Ugaste, 2010) and their effectiveness (Boyd et al, 2009; Gray, Bastian \& Fortner, 2011) and the teachers' learning process has an influence on the quality of school education. It has been recognized that improvements in science teacher training may help pupils to achieve better results in science (Heller, et al., 2012; Munck, 2007; Science Education in Europe: National Policies, Practices and Research, 2011) and thus understand more global processes and sustainability (cf. Carter, 2012). Therefore, support of science teachers' learning progressions should be a constant focus for teacher educators: understanding how students learn about teaching science is essential for developing programs to meet their needs at every step of their career (Schneider \& Plasman, 2011). 
Despite such importance, however, relatively few studies have examined pre-service teachers' approaches to science teaching - few researchers have examined what, why and how science is taught (Nilsson \& Loughran, 2012; Gerretson, Iliško \& Fortino, 2010). Neither are there longitudinal studies of science teachers' learning processes (Schneider \& Plasman, 2011). This issue has arisen because teaching in general has been regarded as a complex and multidimensional process that requires deep knowledge and understanding in a wide range of areas, and with a wide diversity of groups and individuals (Hollins, 2011; Wallace \& Loughran, 2012). Moreover, if education is redefined to include global existential and value-laden aspects, as it is the case with ESD (Pipere et al, 2010), the teaching context is very broad and constantly changing. Besides the wide teaching context and peoples involved, personal factors such as depth of learning experiences (Korthagen, 2004) and teaching related achievement emotions (cf. Pekrun, et al., 2007) influence teachers' learning. Emotions and depth of learning are factors indicating personal characteristics of learning while pedagogical content knowledge (PCK) is construct, which helps describe content of those experiences. This study aims to contribute to a understanding of future primary teachers' personally significant learning experiences about science teaching, how the most significant learning experiences about science teaching are related to different domains of PCK, how deep their learning experiences about science teaching are, and what meaning teachers give to their learning experiences. Knowledge about student teachers' learning in primary science class can contribute to the design and development of sustainability oriented primary teacher education more deeply than politically symbolic rhetoric appearing in teacher education programs (cf Álvarez-García et al, 2015).

\section{Meaningful Teaching Experiences}

The importance of experiences during school placements in teacher education has emerged very clearly from studies (e.g. Avraamidou \& Zembal-Saul, 2010; Timoštšuk \& Ugaste, 2010) and, it has been shown in science teaching in particular, that deliberative experiences shape students' teaching. Incidental learning (often referred to as "teaching experience") seems to have little effect on the development of subject related knowledge (Kleickmann, et al., 2013). Studies, however, of student experiences of teaching science in schools (as reflected in student teachers' identity surveys) do show that experiences effect orientation, professional development and future career goals (cf. Moore, 2008). Those findings support claims that learning is fundamentally experiential and social (Wenger, 1998). Many aspects of experience have an impact on teacher development. Wenger (1998) describes a close mutual connection between experiencing, doing, learning and belonging but not all these experiences are equally significant - some connections seem to be much stronger than others (Cousin \& Deepwell, 2005; Trent \& Gao, 2009). Student teachers, for example, found it difficult or simply did not see the necessity, to describe themselves as teachers and/or as learners: any objective of any learning process was mentioned much less than personal experiences (Timoštšuk \& Ugaste, 2012). What students found meaningful was first and foremost their personal experiences connected to the teaching of their own subject and relations with their pupils and supervisors (ibid.), relationships that evoked a variety of emotions - a fact stressed by several authors (Brown, 2006; Flores \& Day, 2006; Poulou, 2007; Rodgers \& Scott, 2008). Thus becoming a teacher is a highly emotional experience (Malderez et al., 2007). 
During teaching practice students are learners in an achievement-related situation. At this stage of professional development supervisors and students can give almost immediate feedback and evaluation can be made of almost all teaching methods students use in classroom. The emotions students experience can be described as "achievement emotions" (c.f. Heckhausen, 1991). Achievement emotions such as enjoyment of learning, hope, pride, anger, anxiety, shame, hopelessness, or boredom are seen as directly tied to achievement activities or outcomes (Pekrun et al. 2007). Thus emotions not only illustrate students' actions but reveal student's intentions to implement or avoid certain kind of activities.

Whilst contexts and relationships describe external aspects, emotions describe the internal, meaning-making aspects of teacher development. The meaning people give to activities is reflected in the emotions they express to describe their experiences (cf. Zembylas, 2007). Therefore, student emotions about teaching can help teacher educators to understand the most meaningful and significant teaching experiences.

\section{The Student Teachers' PCK}

The complex process of teachers' learning encompasses both the individual-cognitive and the collective - situative aspects of learning (Wallace \& Loughran, 2012). Not ignoring the complexity of learning about teaching, but searching for focus of analysis the study is concentrating on student teachers' state of personal knowledge about teaching more specifically on the domains of teachers' "pedagogical content knowledge" (PCK), a concept introduced by Shulman (1986). PCK is a helpful and widely used construct to aid our thinking about how science teachers learn and what they know about teaching (Loughran, Mulhall \& Berry, 2008; Schneider \& Plasman, 2011). It is unique to teaching and the key to development of expertise (Shulman, 1986) - learning to feel and know like a teacher means utilizing knowledge used and developed in teaching practice (Freiman-Nemser, 2008).

Thus, the concept can be helpful to describe the result of significant learning experiences teacher students recognize during teaching science. In this study the broad description of Schneider and Plasman (2011) is followed who (in studies of the last two decades) have identified five broad fields of PCK (1) orientation and motivation to teach science, (2) thinking about science, (3) instructional strategies in science teaching, (4) the science curriculum, and (5) assessment of students' science learning. All those aspects of PCK contain topics helping teachers to implement ESD supportive practice (cf. Bentham, 2013).

PCK is, however, more than the sum of these constituent parts: teachers do not only possess PCK, they employ the components of PCK in an integrated fashion as they plan and carry out instruction (Abell, 2008). For example, science teaching orientation and motivation to teach science has dimensions such as achieving goals, the purposes of science teaching, views of science, that shape teaching practice and influence other components of PCK (Friedrichsen, Van Driel \& Abell, 2010). Teacher views of teaching and learning science, moreover, can be influenced and changed by teaching context and by conceptual changes in science teaching (Duit \& Treagust, 2012). Thus PCK is a highly complex, personal and situation-specific (Van Driel \& Berry, 2012) form of professional knowledge (Schneider \& Plasman, 2011) and capturing it in practice has proved exceedingly difficult (Loughran, et al. 2008; Nilsson \& Loughran, 2012). Notwithstanding 
this, pre-service teachers face high expectations from their supervisors and pupils from their very first step in teaching.

All student teachers, should, ideally, reflect on and process new experiences and learn to implement knowledge under the supervision of experienced teachers but studies have shown that differences in their PCK can cause a variety of tensions (Nilsson \& Van Driel, 2010). For example, while student teachers concentrate primarily on classroom situations and activities (Brown, 2007; Sikka \& Timoštšuk, 2008), experienced teachers tend to be more aware of broader contextual factors e.g. changes in educational law, international initiatives and professional responsibilities (cf. Teaching and Learning International Survey, 2009) or of science content representation (Loughran, Milroy, Berry, Gunstone \& Mulhall, 2001). Tensions caused by differences in understanding and subsequent development are recognized as part of the emotional background of learning to teach (Maldarez et al., 2007; Poulou, 2007; Timoštšuk \& Ugaste, 2012). Zembylas (2007) sees the development of PCK and emotions as irrevocably interrelated. More positive emotions were found to occur in teaching situations when more effective teaching strategies were implemented. A more detailed knowledge about the state of student teachers' science PCK is valuable for teacher educators and can be used to develop teacher education courses.

\section{Levels of Student Teachers' Learning}

The complexity of student teachers' experiences can be explored when one considers that learning influences not only several domains of PCK but can also reach into different levels of a teachers' personality. Korthagen (2004) differentiates levels of change as follows: at first, teachers' pay most attention to the environment and their own behavior the shallower stratifications of change. These changes are followed by deeper layers of change in the teachers' self; namely, in competencies, beliefs, professional identity, and mission (Korthagen 2004; Meijer, Korthagen \& Vasalos, 2009).

These processes and changes mutually influence each other. What takes place in the deeper level has an effect on the shallower levels and vice-versa (Korthagen, 2004). Korthagen and Vasalos (2005) describe the deeper layers of change (identity and mission) as the core of one's personality. Learning to teach can simultaneously change both student teachers' and in-service teachers' PCK and other teaching-related personal qualities. Van Huizen et al. (2005) specify that the overall aim of a teacher education programme is best conceived as a development of professional identity and that initial education is an important time for students to begin to create a solid teacher identity that will support and sustain them. There is a general consensus that beliefs (both epistemological and pedagogical) are part of a group of psychological factors that affect the structure and content of the human mind presumed to drive actions (Bryan, 2012). Thus beliefs are related to the teaching practices student teachers implement in the classroom (Bryan, 2003). Bryan (2003) highlights beliefs as a significant factor of professional development specifically in the education of primary school science teachers.

While concentrating on deep levels of learning, it was noted that student teachers highlighted intense experiences and related contextual factors (Timoštšuk \& Ugaste, 2012). Students focused most on their own subject and relationships with pupils and supervisors: these were seen to be more important than the broader context of teaching (e.g. cooperation with other teachers or a sense of professional mission). These findings are 
supported by several others studies (Brown 2006; Flores and Day 2006; Poulou 2007; Rodgers and Scott 2008; Timoštšuk \& Sikka, 2008). Although it is also recognized that teachers' learning is related to personal qualities there is little information about this.

\section{The Focus on Teaching in Primary School}

Modern children are growing up in a world where they will need to apply and communicate ideas, make sound decisions based on factual evidence and to collaborate with others to solve problems and make sustainable decisions. These activities require a deep and interconnected understanding of the fundamental ideas underlying these issues (Fortus \& Krajcik, 2012; Pipere, Veisson, Salīte, 2015). The essential characteristics of science education, therefore, are driven by a broad understanding of "science" including SD supportive knowledge and skills (cf. Bentham, 2013). The simplest way to describe science is an endeavour with three distinct but interrelated aspects, namely (a) body of knowledge, (b) method or process, and (c) a way of knowing or constructing reality (Lederman, Lederman \& Bell, 2004). Primary science has, accordingly, to be understood and addressed as both a product and a process involving people (cf. Newton \& Newton, 2001). Conducting a science class with such demanding aims is an especial challenge for primary school teachers because they are generalist teachers with a wide variety of aims who must be competent in many subject fields whilst building a base for further specific science learning. This is not an easy task. Subject-matter knowledge and appropriate methods for teaching science are on-going issues for the international science education community (Anderson \& Clark, 2012; Appelton \& Kindt, 1999; Science Education in..., 2011). There are evidences related to the relationship between teachers' instructional strategies and pupils learning outcomes in primary science (Heller, et al. 2012) but there is no clear connection between science knowledge and the ability to teach that knowledge (Lloyd, Smith, Fay, et al., 1998). Thus, in the debate about primary science teaching, there is a greater focus on teaching and learning related issues are more in focus than subject related issues. Munck (2007), for example, noticed that teachers may believe that they are teaching science using inquiry pedagogy and meeting standards, when they are, in fact, extending teacher-centered instructional methods. Elementary teachers also demonstrate different levels of epistemological understanding of pupils' learning and teaching (Kang, 2007) including dealing with pupils' misconceptions about science (Gomez-Zweip, 2008). Similar issues occur in studies of student teachers. Several studies describe specific subjectrelated challenges faced by pre-service teachers in the primary science classroom. These difficulties include implementing science inquiry teaching (Biggers \& Forbes, 2012; Yoon, Young \& Kim, 2012), problems in teaching school science as argument (ZembalSaul, 2009) or in adaptation of curriculum materials (Forbes \& Davis, 2008, 2010). Difficulties found in primary science teaching for student teachers are: understanding characteristics of pupils' ideas, understanding learners different from themselves, finding balance between freedom and structure and the characteristics of the situation they have in practice (Davis \& Smithey, 2009, c.f. Otero \& Natan, 2008).

Chang (2009). In order to gain a more complete picture about student teachers' learning experiences in science teaching we should simultaneously consider subjectspecific aspects and the personal dimension of learning as important. The purpose of the study is to focus on future primary school teachers' personally significant science teaching experiences in order to analyze their learning. 


\section{Research Method}

\section{Aims and the Procedures}

The study investigates future primary teachers' significant learning experiences about science teaching, how the most significant learning experiences about science teaching are related to different domains of pedagogical content knowledge (PCK) and what meaning teachers give their learning experiences.

Embedded mixed methods were used to get a richer variation of the phenomena under study (Creswell, 2008; Miles \& Huberman 1994). We wanted to embed information from quantitative strand (questionnaire) from another data set (focus-group interview) within a qualitative design framework. The aim of this approach was to support and supplement one method of the study with information from another method (Creswell, 2008; Schram, 2014). Data was collected in stages.

In the first stage a questionnaire about learning experiences was used consisting of the questions: (1) Think about your experiences as primary science teacher. Underline from the listed emotions the one that prevailed: Pride, enjoyment, hope, anxiety, anger, and shame; (2) Describe one typical situation in a science class that evoked the most dominant emotion; (3) Did something change during teaching science in your a) behavior, b) competencies, c) beliefs, d) professional identity, f) mission. If so, give examples and explain more.

The first two questions were about the prevailing achievement emotion (Pekrun et al., 2007) in science teaching and about typical situations related to this emotion. The third question was based on the concept of layers of change in teachers' learning (Korthagen, 2004; Korthagen \& Vasalos, 2005; Meijer, Korthagen \& Vasalos, 2009).

In the questionnaire it was possible to map only the students' opinions therefore focus group interviews were carried out in order to get more profound and more exact information. Focus group interviews were also conducted with the same students to hear the voices of the participants (Denzin \& Lincoln, 2000). The interactions among the participants stimulated them to state feelings, perceptions and beliefs that they would not express if interviewed individually. In the interview the questions in the questionnaire were repeated and the students were asked for additional comments. For example, they were asked to explain thoroughly, describe and give subjective examples of their emotional experiences during science teaching.

The data collection instruments were worked out and validated in cooperation with experienced university teachers. The questionnaire for individual student teachers took 30 minutes to fill. The four focus group interviews, each of them lasting for about one hour, were conducted by the author of the article.

\section{Participants}

The sample consisted of 25 Tallinn University students that started the primary school teacher program in 2009 (primary teachers in Estonia teaching majority of subjects to pupils from age 7-11). Purposeful sampling was the idea behind the selection - the intention was to select those students who could develop a detailed understanding of the theme (Patton 1990).

Students' experiences at the end of their first teaching practice were explored. The first practice took place in the middle of the third year of the student teachers' five-year 
study program. The student teachers spent eight weeks in school teaching all subjects including two science lessons a week. Before the practice the student teachers had been taught science studies and studies about science teaching in university. Student teachers have a second teaching practice during their pre-service course. This final practice takes place for eight weeks in the fourth year of study. Thus experiences after the first teaching practice can more directly characterize the influence of theoretical university studies on student teachers learning about science teaching and the first experience of bridging the theory - practice gap can potentially evoke significant learning experiences.

All students who had finished their first teaching practice in year (2012) in Tallinn University participated. Students were divided into four subgroups of six-seven people. All the student teachers took part in the research voluntarily.

\section{Data Analyses Methods}

The data collected from questionnaire and from interviews was transcribed and analysed in sets using the NVivo7programme. Data analysis units were formed from texts (using one word, a sentence or several sentences cf. Chi, 1997; Basit, 2003) that contained an expression of similar thought. The first two questions were analyzed by the occurrences of the most prevalent achievement emotions and related experiences were analyzed into five areas of science PCK (1) orientation and motivation to teach science, (2) thinking about science, (3) instructional strategies in science teaching, (4) a science curriculum, and (5) assessment of students' science learning (Schneider \& Plasman, 2011).

The examples of coding of data units according to PCK areas of experience were as follows: (1) orientation and motivation to teach science (my view about science as a useful lesson for children's understanding about the world became much stronger), (2) thinking about science (I am wondering what I do not yet know about the nature of science), (3) instructional strategies in science teaching (group discussion is an extremely challenging method for me in science class), (4) a science curriculum (I know now that the facts about water circulation are reflected in the curricula), and (5) assessment of students' science learning (I tried to choose more various tasks by creating worksheets for assessment).

Answers to third question (Did something change during teaching science in your class?) were used to identify and analyze different aspects of science PCK in different layers of learning (a) behavior, b) competencies, c) beliefs, d) professional identity, f) mission). Both researchers analyzed the data separately before the resulting interpretations were identified and discussed. In case of different opinions initial data was analysed once again and discussed until consensus was achieved among the researchers.

The frequency and relations of units of data were identified (see table 1 and 2). Our aim here was not to quantify qualitative data to elucidate events or views but to indicate the more prevailing tendencies amongst student teachers' significant experiences (cf. Basit, 2003).

\section{Findings}

Dominant experiences in science teaching and then levels of domains of PCK in learning about teaching were identified. 


\section{Domains of Pedagogical Content Knowledge in Significant Experiences in Science Teaching}

Students indicated the dominant achievement emotion they felt during the teaching of science. Then they described the most typical situation related to this emotion. The experience they described was explored by five areas of science PCK: (1) orientation and motivation to teach science, (2) thinking about science, (3) instructional strategies in science teaching, (4) the science curriculum, and (5) assessment of students' science learning.

Table 1

Emotions Indicating Significant Science Teaching Experiences in Different Domains of PCK

\begin{tabular}{lcccccc}
\hline \multirow{2}{*}{ Domain of PCK } & \multicolumn{7}{c}{$\begin{array}{c}\text { Emotions related with student teachers' (n-25) most } \\
\text { significant experience }\end{array}$} \\
\cline { 2 - 8 } & $\begin{array}{c}\text { Pride } \\
(0)\end{array}$ & $\begin{array}{c}\text { Enjoy- } \\
\text { ment }(10)\end{array}$ & $\begin{array}{c}\text { Hope } \\
(4)\end{array}$ & $\begin{array}{c}\text { Anxiety } \\
(11)\end{array}$ & $\begin{array}{c}\text { Anger } \\
(0)\end{array}$ & $\begin{array}{c}\text { Shame } \\
(0)\end{array}$ \\
\hline Orientation to teaching science (4) & 0 & 2 & 0 & 2 & 0 & 0 \\
\hline Pupils' thinking about science (13) & 0 & 5 & 2 & 6 & 0 & 0 \\
\hline $\begin{array}{l}\text { Instructional strategies about } \\
\text { science (21) }\end{array}$ & 0 & 9 & 5 & 7 & 0 & 0 \\
\hline Science curriculum (5) & 0 & 1 & 0 & 4 & 0 & 0 \\
\hline $\begin{array}{l}\text { Assessment of students' science } \\
\text { learning (10) }\end{array}$ & 0 & 10 & 0 & 0 & 0 & 0 \\
\hline
\end{tabular}

The dominant emotion for the majority of participants during teaching practice was anxiety (11 students). Beginners especially experienced anxiety because of the complexity of teaching and the uncertainty of achieving demanding goals. Almost as many students (10) mentioned enjoyment as their dominant emotion. Thus the ratio of students with prevalent positive and negative achievement emotions was quite similar. Hope was also indicated as a prevailing emotion (by four students) but other emotions (pride, anger and shame) were not indicated.

In describing their significant experiences most student teachers also mentioned several matters related to different domains of PCK.

In the emotional experiences examples the most dominant domain of PCK was instructional strategies about science (21) thus revealing the task oriented nature of teaching practice. Students were mostly concerned about how they would deliver science knowledge to their pupils. Students felt more enjoyment (9) and hope (5) about classroom instruction, but anxiety (7) persisted. The relatively equal ratio of positive and negative emotions here indicates the complex nature of student teaching practice. Although they know how ideas about learning strategies must be implemented, they struggle with the conflict between a rapid flow of activities and everyday habits in the classroom. Success in the implementation of both traditional and innovative teaching methods produced mostly positive descriptions:

I liked the situations where pupils worked enthusiastically with me even with traditional materials. The idea of linking science texts with creative tasks such as a presentation or a short script for discussion about a topic reflected very effectively on pupils learning outcomes. 
Even if some pupils did not want to be involved in science experiments I tried to engage them in my lessons. I realized that they just did not have the skills for conducting experiments. I love the opportunity to help them master those skills and I hope they will become more enthusiastic about experimenting and investigating new ideas.

Anxiety was expressed more in relation to the demanding nature of science topics and the fear of making mistakes during complex instructional strategies. A lack of knowledge about science content matter seems to cause serious doubts about the implementation of proper teaching methods in the classroom.

I like the general idea of motivating pupils and doing hands-on research but somehow I have to support learning and I am not sure if I can do this for all pupils.

Sometimes I panic if students ask me something during discussion so I tend to avoid situations where they can surprise me. I know that this not right but it the only way I can get through the lesson.

Student teachers expressed a hope of managing better in the future by mastering their ability to use different teaching methods and learning more about science.

The pupils thinking about science was described in 13 examples. Almost half of the examples (six) described the anxiety of students about pupils' previous knowledge of science concepts or about attitudes the pupils have about science:

My pupils' background is so different. Some of them like nature and some do not. One of my pupils described the worm-farm at her home and some others expressed disgust and ignorance of this. I felt disappointed that there are such different attitudes to nature in my classroom but I realize that it might be the same in other topics in science. This is not easy to cope with.

Anxiety was mostly related to personal expectations of how pupils should think. A range of values and beliefs of pupils about science, however, is inevitable in the classroom and these differences are a considerable factor in teaching. This fact seems to be a difficult consideration for student teachers.

On the positive side, many examples (five) described the enjoyment caused by posing relevant questions or the pupils understanding of science.

Often pupils gave specific examples or interesting explanations about concepts. When the topic was interesting and somewhat familiar to them, I felt a warm flow in the classroom.

Experiences based in real life and the relevance of learning content made learning and teaching a more positive experience.

Some students (two) looked forward to and expressed a hope that they would play a positive role in supporting pupils' ability to develop their science knowledge.

I still hope that my efforts were worth something. At least I have the feeling that I taught science in a more interesting way and this must affect pupils' knowledge.

This example indicates a growing sense of the professional mission of student teachers. 
Experiences related to orientation to science teaching and the science curriculums were mentioned less than others - four and five times respectively. This result indicates less significant fields of PCK for student teachers. Although the topics of content and positive orientation to the subject are stressed both on the national level and worldwide, these topics are not yet recognized as very important by student teachers. Orientation to science teaching was related to enjoyment and anxiety but (in both cases) mentioned only twice. The examples student teachers gave were quite simply about pupils' desire or reluctance to learn science.

Experiences about the science curriculum were more negative than positive. The dominant emotion was anxiety and examples revealed gaps in knowledge of the science curriculum.

Surprisingly assessment of student teachers learning was mentioned in relation to enjoyment (10 examples) but with no other emotions. Topics of assessment in science tend to be considered as quite complicated but student teachers seem to use assessment as a quick route to constant feedback about their success or failure.

I like to check what pupils know. It gives me feedback on how well I teach. I was very glad if something we did or talked about in the class was correctly presented in the test.

This positive attitude to assessment helps student teachers to deal with the complex nature of the issue.

\section{Levels of Change and Domains of PCK in Learning about Teaching}

Students described how teaching science changed them at different levels: a) behavior, b) competencies, c) beliefs, d) professional identity, e) mission. They also described several teaching related matters at different levels in one example. Their statements were analyzed in relation to different domains of PCK.

Table 2

Levels of Change of Student Teachers' $(n=25)$ in Domains of PCK

Levels of student teachers' change

Domain of PCK (number of examples)

\begin{tabular}{lccccc} 
& $\begin{array}{c}\text { Behavior } \\
(19)\end{array}$ & $\begin{array}{c}\text { Competencies } \\
(18)\end{array}$ & $\begin{array}{c}\text { Beliefs } \\
(16)\end{array}$ & $\begin{array}{c}\text { Professional } \\
\text { identity (3) }\end{array}$ & $\begin{array}{c}\text { Mission } \\
(22)\end{array}$ \\
\hline Orientation to teaching science (14) & 2 & 1 & 5 & 3 & 3 \\
\hline Pupils' thinking about science (21) & 4 & 3 & 3 & 0 & 11 \\
\hline $\begin{array}{l}\text { Instructional strategies about } \\
\text { science (37) }\end{array}$ & 12 & 12 & 7 & 0 & 6 \\
\hline Science curriculum (5) & 0 & 2 & 1 & 0 & 2 \\
\hline $\begin{array}{l}\text { Assessment of students' science } \\
\text { learning (1) }\end{array}$ & 1 & 0 & 0 & 0 & 0 \\
\hline
\end{tabular}

The majority of examples of change were described on the level of mission (22 examples). Students explained how they learned about their positive role in pupils' science achievements and thinking about science. The general role of the teacher as a promoter of the social aspects of learning was also recognized. A prudent attitude to the influence 
of the teaching profession and respect for pupils' individuality was mentioned several times. This result indicates the strong sense of teaching ethics by student teachers.

I can understand now what a teacher can do with pupils. I can make them laugh or be serious, curious or inert. But I have to be very careful how I use (or do not use) my power as a teacher. Knowledge is power too.

Changes of behavior were described 19 times and changes of competencies were described 18 times. As we have seen, those levels of change are not easy to distinguish for student teachers. The examples they gave were quite similar. For a beginner it is not always simple to estimate a performance or act that is just a result of improvisation (in response to certain circumstances) or conscious and repeatable actions. In both cases most examples expressed experiences related to instructional strategies and are similar to descriptions of experiences related to emotions. The interaction with pupils and success in implementing appropriate teaching methods prevailed. Other domains of PCK (beside instructional strategies) were less mentioned. Some other examples indicated how student teachers learned to respond differently to pupils thinking about science. Students' recognized a change in themselves while supporting pupils to develop a more positive attitude toward science and a personal ability to be more science oriented.

Changes of beliefs were also described many times (16 examples) and, once again, the most important domain of PCK on this level was science teaching instructional strategy. The majority expressed changes of attitude about the effectiveness of various teaching methods but also towards pupils in general. A tendency to believe more in pupils' ability to learn complicated ideas and to learn by different (even non-traditional) activities was revealed. The result supports the idea that theoretical knowledge about new pedagogical concepts and teaching methods must be implemented in practice to enable a shift in personal beliefs and to espouse these beliefs for future use.

I believe pupils are more motivated to learn science then I originally thought.

If we can give them interesting tasks even for less exciting topics, they can learn about quite complicated ideas such as photosynthesis.

Changes of professional identity were mentioned only three times in relation to orientation to teaching science. The majority of students did not experience deep significant changes in their personality during teaching practice. The result indicates that the state of professional identity may be quite stable but the study does not reveal the characteristics of a primary science teaching identity. Still, some examples show that a significant deep change during the teaching practice does exist.

I feel different now - I do the right things for my pupils. They can learn more about the world with me.

In describing learning experiences on different levels, students often revealed what emotions they felt. Anxiety was the dominant emotion here but, as in the answers about the most dominant emotion, enjoyment was also the next important emotion. In several cases student teachers expressed the complexity of their experience in one single example.

I learnt to observe myself and feel confident to teach. I am happy but sometimes I am still afraid of mistakes.

Complexity was mentioned but still a positive attitude and a hope for professional growth was recognized. 


\section{Discussion and Conclusion}

The study provides information about future elementary school teachers' significant learning experiences during science teaching and enables an exploration of their perceptions of their learning experiences. Different domains of PCK crop up in those experiences. The uneven distribution of domains reveals potential areas for teacher education.

Significant experiences were indicated in relation to achievement emotions felt. Student teachers' experiences during science teaching were related to anxiety and enjoyment and each emotion was given almost equal weight. Several authors recognize anxiety as the prevailing, unconstructive emotion in student teaching (Chang, 2009; Poulou, 2007), but enjoyment as a teaching related emotion has not been broadly recognized in previous studies. Yet, as Janssen and others (2008) have noted, student teachers that have positive teaching experiences and who habitually reflect on them, produce more innovative resolutions and are more highly motivated to implement these resolutions in classroom instruction. This concurs with the results of our study - twice the number of students described positive experiences and mentioned PCK components at the same time as those who described negative experiences. Our findings suggest that teacher educators should pay more attention to supporting, recalling and reflecting on positive emotions and reducing anxiety related mostly to poor knowledge about science concepts. On the other hand, our result highlights the importance of the solid science knowledge base in primary science teacher education recognized by several authors (e.g. Heller, et al., 2012). Better content knowledge may help student teachers to avoid stress and remain more positive. We suggest that an emphasis on science knowledge should be made earlier than during teaching practice. One possible way to strengthen teacher education programs could be the implementation of special courses or to set higher requirements concerning science knowledge for entrance to primary teacher education.

The most dominant area of PCK in students' significant experiences during teaching practice was classroom instruction. This supports earlier studies (e.g. Brown, 2007) about the importance of the immediate environment and the reaction of pupils to student's opinions of learning. Student teachers, however, expected to understand the significance and value of all domains of PCK as equally important. The fact that other domains of PCK in student learning are twice or less significant, can reveal reasons why primary science teachers do not meet all the expectations of supervisors, teachers and pupils. It is very hard to expect student teachers to teach differently if there is little information about their learning experiences, about the science curriculum or about the assessment of pupils' science learning (cf. Kang, 2007). These areas of PCK should be better integrated into teaching practice in initial teacher education. Reflection on the curriculum and the assessment of issues with supervisors and teachers might help students to recognize significant issues that reflect also on other fields of PCK (Nilsson \& Van Driel, 2012).

Another dimension (beside content of learning) is level of learning. Students described how they changed during teaching science on different levels. The majority of examples were described at the level of mission. Mission here is closely related to the idea of science teaching orientation defined by Friedrichsen et al (2010) - that is, as a set of beliefs including the dimension of goals and the purposes of science teaching. Students described how they learned about their role in pupils' science achievements and thinking about science. The result reveals a deep, positive impact of practice on student teachers' understanding of a teacher's role in supporting pupils' thinking about science. The result 
also supports findings about future primary teachers' rich and changing views concerning pupils' prior knowledge and learning (Otero \& Nathan, 2008). Changes of behavior, competencies and beliefs were also described many times, mostly in relation to instructional strategies. This result concurs with other findings about the importance of the immediate environment and partners in learning (Korthagen \& Vasalos, 2005). As other domains of PCK were less mentioned in relation to changes in behavior, competences and beliefs, it may be advisable to have more discussion of areas of PCK beside instructional strategies in teacher education in order to help develop a more a holistic view of science teacher competencies.

Changes of professional identity were mentioned by student teachers only a few times. This result could point to an underestimated resource issue for teacher education. Positive changes in professional identity (such as a more complex view of personal professionalism or a more solid identity) may help student teachers to decide to enter and to sustain their interest in the teaching profession. Reflection on changes in professional identity and discussions about relevant factors could help student teachers to understand their learning experiences more deeply (cf. Meijer, et al., 2007).

It is to be noted that the majority of examples from student teachers missed out specific science-related and sustainability oriented details of their learning experiences. The expression of general pedagogical ideas was dominant. This indicates that student teachers' significant experiences are more related to pedagogical knowledge then knowledge of science. Primary science, however, is driven by a broad understanding of "science" (cf. Lederman, Lederman \& Bell, 2004) and thus more specific details about the process and products of science including sustainability should be a focus of initial teacher education.

Although all student teachers from the primary teacher education program who had finished their first teaching practicum in Tallinn University participated in this study, the number of participants is relatively small. This problem was understood and different types of qualitative data collection strategies (interviews, open ended questions) were used. Despite rich qualitative data and data analysis in different stages, the study has limitations. The data collected is based on students' self-reports and respondents may tend to express themselves more positively or in a more socially acceptable way. For that reason, achievement emotions as indicators of significant experiences have been treated cautiously in this study. Frustration, for example, is a more socially acceptable emotion than anger and students could tend to report frustration more easily. Anger, moreover, may turn into frustration if the student teachers feel there is nothing they can do about repeated misbehaviour or awkward situations (Chang, 2009). Anxiety linked to possible failure may also be connected with anger. The study, therefore, has no intention of exploring emotions as key characteristics of student teacher's experiences.

Beginner (Initial) science teachers tended to describe their teaching practices as very leaner-centered but external observation contrasted starkly with their beliefs: they behaved in teacher centered ways (Simmons, et al., 1999). Thus studies that follow up the observation data collected about student teachers' PCK could contribute to a more complete understanding of primary science teacher learning (cf. Abell, 2008). Longitudinal data too may be considered as components of follow up studies. The process of primary student teachers' professional identity building should also be explored more in future studies. The danger of self-reporting was minimized by asking the same questions twice - once in questionnaires and once during small group interviews in a room adapted 
specially for this use. The focus group interviews provided an opportunity for the students to support each other and to help with the recall of significant incidents.

Considering the relatively small number of participants in this study, a comparative study of student teachers' learning experiences in a different context with a larger sample might be carried out in the future. Studies of different types of teacher education programs from different universities from different countries can be conducted.

As this study highlights gaps in student teachers PCK it could also be considered (among other issues that should be further explored) as background information for designing more specific practical tasks for use during teaching practice.

\section{References}

Abell, S. K. (2008). Twenty years later: does pedagogical content knowledge remain a useful idea? International Journal of Science Education, 30(10), 1405-1416.

Álvarez-García, O., Sureda-Negre, J., \& Comas-Forgas, R. (2015). Environmental Education in Pre-Service Teacher Training: A Literature Review of Existing Evidence. Journal of Teacher Education for Sustainability, 17(1), 72-85.

Anderson, D., \& Clark, M. (2012). Development of syntactic subject matter knowledge and pedagogical content knowledge for science by a generalist elementary teacher. Teachers and Teaching, 18(3), 315-330.

Appelton, K., \& Kindt, I. (1999). Why teach primary science? Influences on beginning teachers' practices. International Journal of Science Education, 21(2), 155-168.

Avraamidou, L., \& Zembal-Saul, C. (2010). In search of well-started beginning science teachers: insights from two first-year elementary teachers. Journal of Research in Science Teaching, 47(6), 661-686.

Basit, T.N. (2003). Manual or electronic? The role of coding in qualitative data analysis. Educational Research, 45(2), 143-154.

Bentham, H. (2013). Clearing the path that has been laid: A conceptualisation of education for sustainable development. Journal of Teacher Education for Sustainability, 15(2), 25-41.

Boyd, D.J., Grossman, P.L., Lankford, H., Loeb, S., \& Wyckoff, J. (2009). Teacher preparation and student achievement. Educational Evaluation and Policy Analysis, 31(4), 416-440.

Biggers, M., \& Forbes, C. T. (2012). Balancing teacher and student roles in elementary classrooms: pre-service elementary teachers' learning about the inquiry continuum. International Journal of Science Education, 34(14), 2205-2229.

Brown, T. (2006). Negotiating psychological disturbances in pre-service teacher education. Teaching and Teacher Education, 22, 675-689.

Bryan, L. A. (2003). Nestedness of beliefs: examining a prospective elementary teacher's belief system about science teaching and learning. Journal of Research in Science Teaching and Learning, 40(9), 835-868.

Bryan, L. A. (2012). Research on science teacher beliefs. In B.J. Fraser, K.G. Tobin \& C. J. McRobbie (Eds.), Second International Handbook of Science Education (pp. 477-495). Springer Netherlands.

Carter, L. (2012). Globalization and science education: global information culture, postcolonialism and sustainability. In B.J. Fraser, K.G. Tobin \& C. J. McRobbie (Eds.), 
Second international handbook of science education (pp. 899-912). Springer Netherlands.

Chang, M. (2009). An appraisal perspective of teacher burnout: Examining the emotional work of teachers. Educational Psychology Review, 21(3), 193-218.

Chi, M. T. H. (1997). Quantifying qualitative analysis of verbal data: a practical guide. The Journal of Learning Sciences, 6(3), 271-315.

Cochran-Smith, M., McQuillan, P., Mitchell, K., Terrell, D. G., Barnatt, J., D’Souza, L., et al. (2012). A longitudinal study of teaching practice and early career decisions. A cautionary tale. American Educational Research Journal, 49(5), 844-880.

Cousin, G., \& Deepwell, F. (2005). Designs for network learning: a communities of practice perspective. Studies in Higher Education, 30(1), 57-66.

Creswell, J. W. (2008). Educational research. Planning, conducting, and evaluating quantitative and qualitative research ( $3^{\text {rd }}$ ed.). New Jersey: Pearson Education.

Davis, E.A., \& Smithey, J. (2009). Beginning teachers moving toward effective elementary science teaching. Science Education, 93(4), 745-770.

Denzin, N. K., \& Lincoln, Y. S. (2000). Strategies of inquiry. Handbook of qualitative research, 2, 367-378. Thousand Oaks, CA: Sage.

Duit, R., \& Treagust, D.F. (2012). How can conceptual change contribute to theory and practice in science education? In B. J. Fraser, K. Tobin \& C. J. McRobbie (Eds.), Second international handbook of science education. (pp. 107-118). Springer Netherlands.

Fisher, H. E., Borowski, A. \& Tepner, O. (2012). Professional knowledge of science teachers. In B. J. Fraser, K. Tobin and C. J. McRobbie (Eds.), Second international handbook of science education. (pp. 435-448). Springer Netherlands.

Flores, M.A., \& Day, C. (2006). Contexts witch shape and reshape new teachers' identities: a multi-perspective study. Teaching and Teacher Education, 22, 219232.

Forbes, C. T., \& Davis, E. A. (2008). Curriculum design for inquiry: pre-service elementary teachers' mobilization and adaptation of science curriculum materials. Journal of research in science teaching, 47(7), 820-839.

Fortus, D. \& Krajcik, J. (2012). Curriculum coherence and learning progressions. In B. J. Fraser, K. Tobin \& C. J. McRobbie (Eds.), Second international handbook of science education. (pp. 783-798). Springer Netherlands.

Feiman-Nemser, S. (2008). Teacher learning: How do teachers learn to teach? In M. Cochran-Smith, S. Feiman-Nemser, D. J. McIntyre, \& K. Demers (Eds.), Handbook of research on teacher education: Enduring questions in changing contexts (pp. 697-705). New York: Routledge.

Friedrichsen, P., van Driel, J. H., \& Abell, S. K. (2011). Taking a closer look at science teaching orientations. Science Education, 95(2), 358-376.

Gerretson, H., Iliško, Dz. \& Fortino, C. (2010). Sustaining self-regulated learning through inquiry-driven mathematics and science instruction. Discourse and Communication for Sustainable Education, 1(1), 3-17.

Gray, T. H., Bastian, K.C. \& Fortner, K.C. (2011). Early-career teacher effectiveness and attrition. Educational Researcher, 40(6), 271-280.

Heckhausen, H. (1991). Motivation and action. New York: Springer.

Heller, J.I., Kristen, R.D., Wong, N., Shinohara, M., \& Miratrix, L.W., (2012). Differential effects on three professional development models on teacher knowledge 
and student achievement in elementary science. Journal of Research in Science Teaching, 49(3), 333-362.

Hollins, E. R. (2011). Teacher preparation for quality teaching. Journal of Teacher Education, 64(4), 395-407.

Kang, N.-H. (2007). Elementary teachers' teaching for conceptual understanding: Learning from action research. Journal of Science Teacher Education, 18(4), 469-495.

Korthagen, F. (2004). In search of the essence of a good teacher: towards a more holistic approach in teacher education. Teaching and Teacher Education, 20, 77-97.

Korthagen, F., \& Vasalos, A. (2005). Levels in reflection: core reflection as a means to enhance professional growth. Teachers and Teaching: Theory and Practice, 11(1), 47-71.

Kleickmann, T., Richter, D., Kunter, M., Elsner, J., Besser, M., Krauss, S., \& Baumert, J. (2013). Teachers'content knowledge and pedagogical content knowledge: The role of structural differences in teacher education. Journal of Teacher Education, 64(1), 90-106.

Lloyd, J. K., Smith, R. G., Fay, C. L., Khang, G. N., Wah, L. L. K., \& Sai, C. L. (1998). Subject knowledge for science teaching at primary level: a comparison of preservice teachers in England and Singapore. International Journal of Science Education, 20(5), 521-532.

Loughran, J., Mulhall, P., \& Berry, A. (2008). Exploring pedagogical content knowledge in science teacher education. International Journal of Science Education, 10 (13), 1301-1320.

Loughran, J., Milroy, P., Berry, A., Gunstone, R., \& Mulhall, P. (2001). Documenting science teachers' pedagogical content knowledge through PaP-eRs. Research in Science Education, 31, 289-307.

Lederman, N. G., Lederman, J. S., \& Bell, R. L. (2004). Constructing Science in Elementary Classrooms. New York: Pearson Education.

Malderez, A., Hobson, A. Tracey, L., \& Kerr, K. (2007). Becoming a student teacher: core features of the experience. European Journal of Teacher Education, 30 (3), $225-248$.

Meijer, P., Korthagen, F., \& Vasalos, A. (2009). Supporting presence in teacher education: The connection between the personal and professional in teaching. Teaching and Teacher Education, 25, 297-308.

Miles, M. B., \& Huberman, A. M. (1994). Qualitative data analysis: An expanded sourcebook. Thousand Oaks, CA: Sage.

Moore, F. M. (2008). Professional identity and science teacher professional development. Journal of Research in Science Teaching, 45(6), 684-710.

Munck, M. (2007). Science pedagogy, teacher attitudes, and student success. Journal of Elementary Science Education, 19 (2), 13-24.

Newton, L. D., \& Newton, D. P. (2001). Coordinating science across the primary school. The subject leader's handbook. London: Routledge Falmer.

Nilsson, P., \& Loughran, J. (2012). Exploring the development of pre-service science elementary teachers' pedagogical content knowledge. Journal of Science Teacher Education, 23(7), 699-721.

Nilsson, P., \& van Driel, J. (2010). Teaching together and learning together-Primary science student teachers' and their mentors' joint teaching and learning in the primary classroom. Teaching and Teacher Education, 26(6), 1309-1318. 
Otero, V. K., \& Nathan, M. J. (2008). Preservice elementary teachers' views of their students' prior knowledge of science. Journal of Research in Science Teaching, 45(4), 497-523.

Patton, M. Q. 2002. Qualitative research \& evaluation methods. Beverly Hills, CA: Sage.

Pekrun, R., Frenzel, A. C., Goetz, W., \& Perry, R. P. (2007). The control-value theory of achievement emotions: An integrative approach to emotions in education. In P. A. Schutz, \& R. Pekrun, (Eds.). Emotions in education. (pp. 13-36). San Diego: Elsevier.

Pipere, A., Reunamo, J., \& Jones, M. (2010). Perceptions of research in education for sustainable development: An international perspective. Discourse and Communication for Sustainable Education, 1(2), 5-24.

Pipere, A., Veisson, M., \& Salite, I. (2015). Developing research in teacher education for sustainability: UN DESC via the Journal of Teacher Education for Sustainability, Journal of Teacher Education For Sustainability, 17(2), 5-44.

Poulou, M. (2007). Student-teachers' concerns about teaching practice. European Journal of Teacher Education, 30(1), 91-110.

Rodgers, C. R., \& Scott, K. H. (2008). The development of the personal self and professional identity in learning to teach. In M. Cochran-Smith, S. Nemser-Freiman, (Eds.). Handbook of Research on Teacher Education. Enduring Questions in Changing Contexts. Third Edition. (pp. 732-755). New York: Routledge.

Schneider, R. M., \& Plasman, K. (2011). Science teacher learning progressions. A review of science teachers' pedagogical content knowledge development. Review of Educational Research, 81(4), 530-565.

Schram, A.B. (2014). A mixed method content analysis of the research literature in science education. International Journal of Science Education, 36 (15), 2619-2638.

Shulman, L. S. (1986). Those who understand: Knowledge growth in teaching. Educational Researcher, 15, 4-14.

Sikka, H., \& Timoštšuk, I. (2008). The role of reflection in understanding teaching practice. Problems of Education in the 21st Century, 7, 147-152.

Zembal-Saul, C. (2008). Learning to teach elementary school science as argument. Science Education, 93(4), 687-719.

Zembylas, M. (2007). Emotional ecology: the intersection of emotional knowledge and pedagogical content knowledge in teaching. Teaching and Teacher Education, 23, 355-367.

Timoštšuk, I., \& Sikka, H. (2008). Identity statements of student teachers in the initial stage of teacher training as indicators of environmental, cognitive and relationship mechanisms. In J. Mikk, M. Veisson, P. Luik (Eds.), Reforms and Innovations in Estonian Education (pp. 95-107). Peter Lang Publishers House.

Timoštšuk, I. 2009. Coping of trainee-teachers in influencing pupils' study environment. In J. Hytönen (Ed.), Educational environment in early childhood in Estonia and Finland. IV. Collection of Articles (pp. 75-85). Helsinki: University of Helsinki.

Timoštšuk, I., \& Ugaste. A. (2010). Student teachers' professional identity. Teaching and Teacher Education, 26, 1563-1570.

Timoštšuk, I., \& Ugaste. A. (2012). The role of emotions in student teachers' professional identity." European Journal of Teacher Education, 35(4), 421-433. 
Trent, J., \& Gao, X. (2009). “At least I'm the type of teacher I want to be”: secondcareer English language teachers' identity formation in Hong Kong secondary schools. Asia-Pacific Journal of Teacher Education, 37, 253-270.

Yoon, H.-G., Joung, Y.J., \& Kim, M. (2012). The challenges of science inquiry teaching for pre-service teachers in elementary classrooms: difficulties on and under the scene. Research in Science Education, 42, 589-608.

Van Driel, J.H., \& Berry, A. (2012). Teacher professional development focusing on pedagogical content knowledge. Educational Researcher, 41(1), 26-28.

Van Huizen, P., Van Oers, B., \& Wubbels, T. (2005). A Vygotskian perspective on teacher education. Journal of Curriculum Studies, 37(3), 269-290.

Wallace, J., \& Loughran, J. (2012). Science teacher learning. In B. J. Fraser, K. Tobin and C. J. McRobbie (Eds.), Second international handbook of science education. (pp. 295-306). Springer Netherlands.

Wenger, E. 1998. Communities of practice. Leaning, meaning, and identity. New York: Cambridge University Press.

Science Education in Europe: National Policies, Practices and Research (2011). Eurydice. European Commission. Retrieved on April 18, 2016, from http://eacea.ec.europa.eu/ education/eurydice

Teaching and Learning International Survey (2009). Organization for economic cooperation and Development. Retrieved on April 18, 2016, from http://www.oecd. org/edu/talis/firstresults.

Correspondence concerning this paper should be addressed to Inge Timoštšuk, $\mathrm{PhD}$, Associate Professor, School of Educational Sciences at Tallinn University, Narva mnt 25, 10120 Tallinn, Estonia. Email: inge.timostsuk@tlu.ee 